\title{
斜面災害対策事業における 対策工選定フローの設定に関する一提案
}

\author{
澤田 尚 1 - 杉原 成満 2 - 西村 大喜 3 - 篠崎 嗣浩 4 - 大石 博之 5 -古川 浩平 6 \\ 1正会員＼cjkstart西日本技術開発株式会社（ T810-0004 福岡県福岡市渡辺通1-1-1） \\ E-mail: h-sawada@wjec.co.jp \\ 2正会員 山口大学助教大学院理工学研究科（₹755-8611 山口県宇部市常盤台2-16-1） \\ E-mail: s.sugi@yamaguchi-u.ac.jp \\ 3非会員 山口大学大学院理工学研究科（干755-8611 山口県宇部市常盤台2-16-1） \\ E-mail: j055fd@yamaguchi-u.ac.jp \\ 4正会員 大日本コンサルタント株式会社（テ343-0851 埼玉県越谷市七左町5-1） \\ E-mail: shinozaki@ne-con.co.jp \\ 5正会員 西日本技術開発株式会社（ ( 810-0004 福岡県福岡市渡辺通1-1-1） \\ E-mail: h-ohishi@wjec.co.jp \\ 6フェロー会員 山口大学特命教授 大学院理工学研究科（†755-8611 山口県宇部市常盤台2-16-1） \\ E-mail: furukaw@yamaguchi-u.ac.jp
}

\begin{abstract}
斜面災害対策事業を効率的に進めるためには，斜面ごとの危険性を把握し，適切な対策工を計画するこ とが重要である。本研究では，サポートベクターマシーンを活用し，危険斜面に対する対策工選定フロー の設定を試みた。まず地形・地質的な素因と過去の災害履歴を用いて，対策工の有無や工種ごとに斜面危 険度の評価基準の設定を行う。これらの評価基淮から現在の斜面危険度と新たに対策工を追加した場合の 斜面危険度の算出を行う。これにより，斜面ごとにどのような対策工が最も効率的であるかを評価するこ とが可能となる。対策工選定フローにより対策が必要と判断された箇所の現地調查によると, 対策工選定 の結果が現地状況から得られる技術者の知見と一致していた，そのため，これらの成果は防災事業計画の 検討において有効な手段であると考えられる.
\end{abstract}

Key Words : support vector machine, slope disaster, countermeasure, risk evaluations

\section{1. はじめに}

斜面災害の抑止には，擁壁工や法枠工などに代表され るハード対策（以下，対策工）の施工が効果的である. しかしながら，これらを必要とする危険な斜面（以下， 危険箇所）が多いこと，近年の経済状況から対策工を施 工寸るための予算確保が困難なことなどの理由により， 斜面災害対策事業の進展がはかれず，現状の対策工の整 備率が低いという実情がある。このため，今後，すべて の斜面に対策工を施工寸ることは費用面・時間面からも 困難であると考えられる.

このような状況に対し，急傾斜地崩壊危険箇所調查力 ルテ1)などの既存データを活用して，個々の斜面が有す る危険性を把握し，目的や機能が異なる対策工の中から 最適な対策工を選定することが可能となれば，先の費用
面や時間面の課題に対寸る一つの解決策になるものと考 えられる.このような分野に関する既往の取り組みの一 つとして，数理的な手法であるサポートベクターマシー ン2) (Support Vector Machine : 以下，SVM）を用いて地 形・地質的な素因と過去の災害履歴の関係から災害の発 生と非発生を分ける分離超平面（以下，分離面）を設定 し, 当該分離面加らの距離を危険度として算出する方法

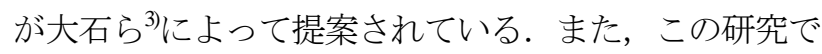
は，対策済の斜面データから設定した分離面に基づく危 険度と無対策の斜面データから設定した分離面に基づい た危険度とを比較することにより，対策工効果を定量的 に評価する方法も考案されている.

大石 $ら^{3)}$ の研究は, 数理的な手法を用いることにより, 対策工効果を踏まえた土砂災害の危険度評価が行える点 で大きな成果を挙げている，しかしながら，対策工効果 


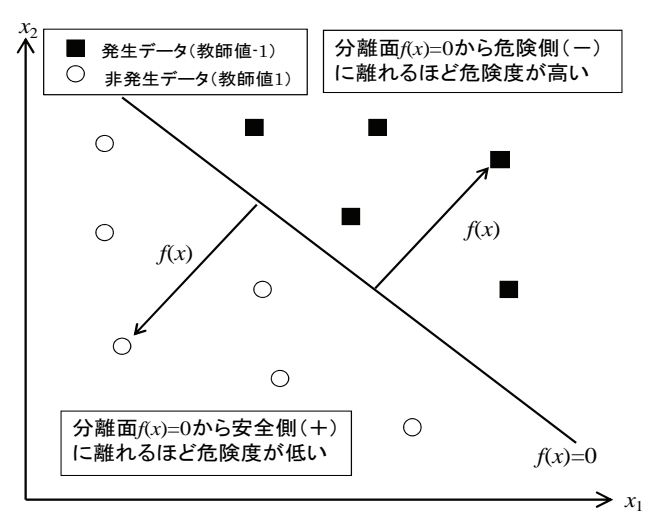

図-1ＳVMの概念図

の評価にあたっては，対策工の有無にのみ着目し，擁壁 工や法枠工などのように異なる目的や機能を持つ個々の 工種についての対策工効果については評価がなされてい ない，そのため，対策工効果を踏まえて効果的な工種を 選定するためには，工種ごとの対策工効果や複数の工種 を組み合わせて用いた場合における対策工効果の評価を 行うことが必要となる.

そこで, 本研究では, 大石ら ${ }^{33}$ の提案する斜面危険度 および対策工効果の評価方法を活用し，山口県の急傾斜 地崩壊危険箇所の調査データ1)および過去の災害実績)を 用いて斜面災害対策事業における対策工選定フローの設 定を試みた，その結果，設定した対策工選定フローに基 ついた対策工の選定結果は，現地状況から得られる技術 者の知見と一致することが確認された.

\section{2. 対策工選定フローの設定方法の概要}

対策工選定フローの設定にあたっては，大石ら ${ }^{33} の$ 提 案する SVM を用いた危険度評価方法を活用する. 以下 に SVM の概要および SVM を用いた対策工選定フロー の設定手順について述べる.

\section{(1) SVMの概要}

SVMは1995年にCortes \& Vapnikによって提案されたパ ターン分類手法"2)の一である.

SVM の概念図を図-1 に示寸. SVM は，線形分離不可 能なデー夕群を非線形関数を用いることにより高次元特 徵空間にマッピングし, 線形分離可能な状態とすること で明確に分離する機能を持つ。この時，高次元特徵空間 でデータを分離する面を分離超平面と呼ぶ（図-1 の $f(x)=0$ の面. 以下，分離面）。この機能を用いて, 災害 の発生と非発生を判別する分離面と各データとの距離 $f(x)$ を算出することで危険度を評価することもできる ${ }^{3)}$, 5) 本研究では，この危険度評価手法を用いて算出される 現在の斜面危険度 $f(x) 1$, 対策後の斜面危険度 $f(x) 2$ を踏

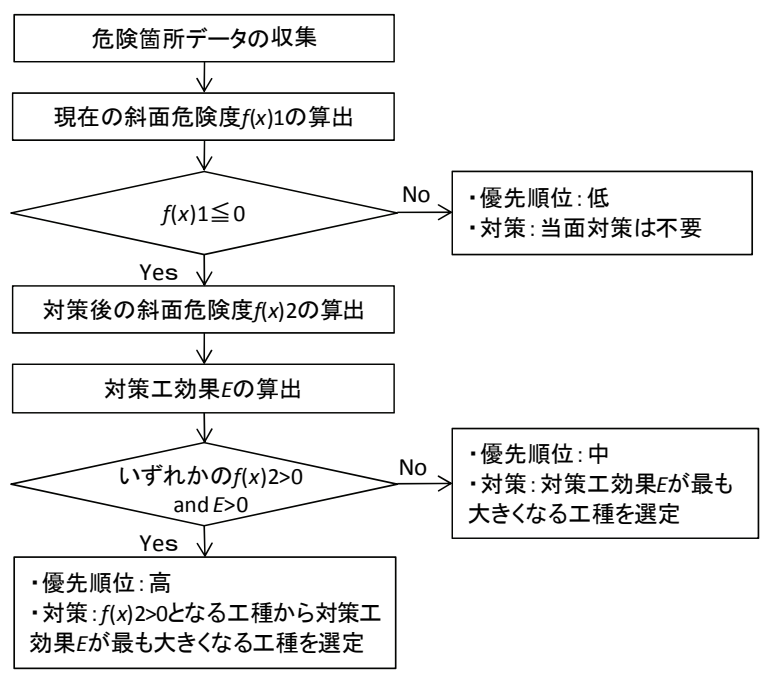

図-2 対策工選定フロー

まえた対策工選定フローの設定を行う。なお，SVM 解 析における教師值は災害の発生を-1，非発生を+1 とした，

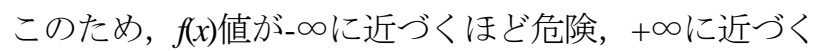
ほど安全と評価することができる.

\section{(2) 対策工選定フローの設定手順}

対策工選定フローにおける対策の要否と最適な対策工 の選定は，現在の斜面危険度 $f(x) 1$ ，対策工の施工後に想 定される対策後の斜面危険度 $f(x) 2$, 斜面危険度の変化量 により算出される対策工効果 $E$ に基づいて行う.

本研究で提案する対策工選定フローを図-2 に示す. また，対策工選定フローの設定手順を以下に示寸.

\section{a) 分離面の設定}

SVM 解析に用いる評価指標は, 各斜面の地形・地質 的な素因とし, 教師值は過去の災害履歴とする. SVM を用いてこれらの関係を分析することで災害の発生と非 発生を判別する分離面を得ることができる.

なお，算出する斜面危険度は，同様の特徽を有する斜 面であっても対策工の有無や工種の違いによって異なる ものと考えられる. そのため, 本研究では個々の斜面デ 一タを対策工の施工されていない斜面，擁壁工のみが施 工されている斜面，擁壁工と法枠工が施工されている斜 面等に分類した上で，分類ごとに斜面危険度の算出に用 いる分離面の設定を行うこととした.

\section{b) 斜面危険度の算出}

現在の斜面危険度 $f(x) 1$ は，評価対象斜面が該当する 分類における分離面と当該斜面データとの距離によって 算出することができる（図-3(a)）。これにより，現在 の斜面危険度を評価することができ，斜面危険度に基づ いた対策の要否を判断することが可能となる.

一方，対策後の斜面危険度 $f(x) 2$ は，任意の対策工が施 工されている斜面が該当する分類における分離面と評価 対象斜面との距離によって算出することができる（図- 


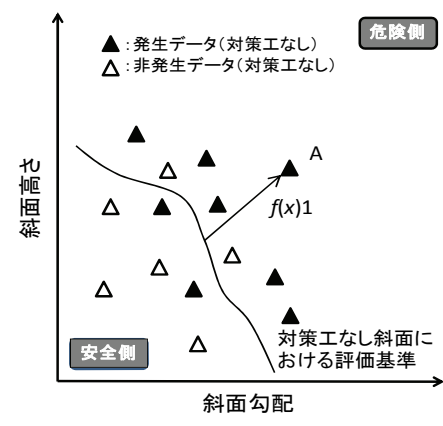

(a) 現在の斜面危険度 $f(x) 1$

(対策工なし斜面の例)

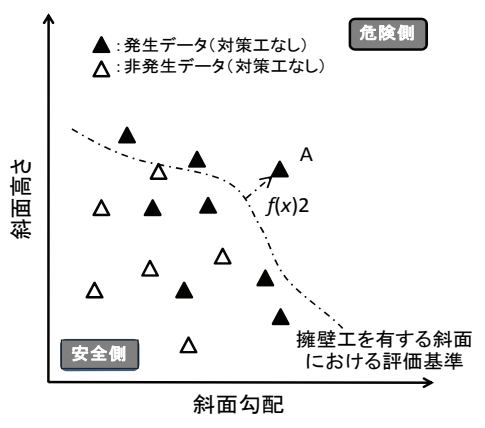

(b) 対策後の斜面危険度 $f(x) 2$ （擁壁工を想定した場合）

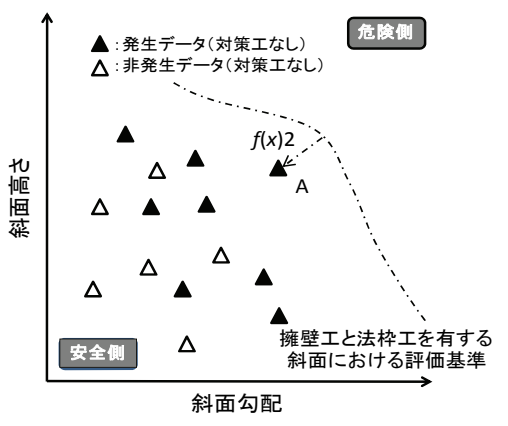

(c) 複数の対策後の斜面危険度 $f(x) 2$ (擁壁工十法枠工を想定した場合)

図-3 斜面危険度 $f(x)$ の算出概念

3(b)，図-3(c)）。これにより，様々な工種について対 策後の斜面危険度 $f(x) 2$ を算出することが可能となる．な お，表層崩壊している斜面において，対策工に擁壁工を 選定した場合, 対策工の工種が適切ではないため, 要因 と対策工の関係に矛盾が生じ，対策工の施工により斜面 危険度が危険側に推移するという評価 $(f(x) 2<f(x) 1)$ と なることも考えられる.このような場合は，対策工の効 果がないと判断できるため, $f(x) 2=f(x) 1$ とする.

また，求めた対策後の斜面危険度 $f(x) 2$ と現在の危険度 $f(x) 1$ との差は，対策工の施工による危険度の変化量であ り，この差を対策工効果 $E$ として考えることが可能であ る3.これらの指標を用いて, 各斜面に対し最適な対策 工を選定することが可能となる.

\section{3. 使用データの概要}

\section{(1) 対象データ}

本研究では, 平成 11 年に作成された急傾斜地崩壊危 険箇所調查カルテ (以下, H11 斜面カルテ) 1)より, 表1 に示す 627 箇所（対策工なし：163 箇所，対策工あ り：464 箇所）を分析対象データとした. なお, 本研究 では工種ごとに分離面を設定した上で，現状の斜面危険 度 $f(x) 1$ および対策後の斜面危険度 $f(x) 2$ の算出を行うこ とから，収集した斜面データについては，表-1 に示す とおり対策工の有無および施工されている工種に基づい て分類を行った．ここに，本研究では，対策工の選定つ ローに従い负険が予測される斜面に対し，妥当な工種と 組合せの抽出を目的としている. このため，対策工の効 果が工種の増加により明らかに高まる組合せとして，擁 壁工，擁壁工十落石防止工，擁壁工十法枠工，擁壁工十 落石防止工十法枠工の計 4 通りの組合せを選定した.

\section{(2) 災害データ}

分析の教師值となる過去の災害データは, H11 斜面力 ルテにおける崩壊履歴および山口県災害報告書 (平成 3
表-1 対策工の工種と箇所数の関係

\begin{tabular}{|c|c|c|c|c|c|}
\hline \multirow{2}{*}{\multicolumn{2}{|c|}{ 工種 }} & \multicolumn{4}{|c|}{ 箇所数 } \\
\hline & & \multicolumn{2}{|c|}{ 発生 } & \multirow{2}{*}{$\frac{\text { 非発生 }}{152}$} & \multirow{2}{*}{$\begin{array}{l}\text { 計 } \\
163\end{array}$} \\
\hline & 対策エなし & & (27) & & \\
\hline \multirow{5}{*}{$\begin{array}{l}\text { 対 } \\
\text { 策 } \\
\text { 工 } \\
\text { あ } \\
\text { り }\end{array}$} & 擁壁工 & 7 & (16) & 222 & 229 \\
\hline & 擁壁工+落石防止工 & 6 & (8) & 92 & 98 \\
\hline & 擁壁エ+法枠エ & 1 & (3) & 39 & 40 \\
\hline & 擁壁工+法枠工+落石防止工 & 2 & (2) & 95 & 97 \\
\hline & 対策エあり小計 & 16 & (29) & 448 & 464 \\
\hline & 総計 & 27 & (56) & 600 & 627 \\
\hline
\end{tabular}

※発生の()書きは疑似データ追加後の件数

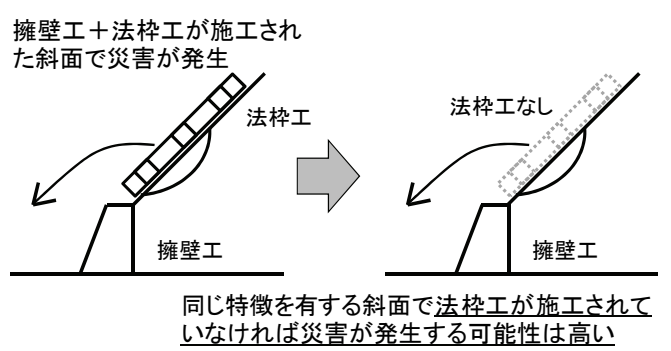

図-4 疑似データとして用いる災害データの概念図

年〜平成 17 年） ${ }^{4} /$ に記載の災害記録を用いる.ただし， 対策工が施工されている斜面については，明らかに対策 工を施工した後に発生した崩壊履歴を用いる必要がある ことから，山口県災害報告書（平成 3 年〜平成 17 年） に記載の災害記録のうち, 斜面カルテ作成以降となる平 成 12 年以降の災害記録のみを用いることとした。

対策工の有無および工種毎の災害発生件数を表-1 に 示す. 表より, 災害発生件数は総計で 27 件と少なく, 工種によっては災害件数が 1 件の工種もある. 本研究で 用いる SVM は，データ分布に基づいて災害の発生と非 発生を分ける分離面を設定する手法であるため, 災害件 数が極端に少ない場合, 分離面の設定が困難となる.

そこで, 本研究では, 対策工により斜面の安全性が増 すものと考え, 対策工の工種が少ない斜面では, 対策工 の工種が多い斜面よりも危険であると仮定した．例えば， 擁壁工と法枠工が施工されている斜面で災害が発生した のであれば，同様の地形・地質的特徵を有する場合，擁 
表-2 使用要因

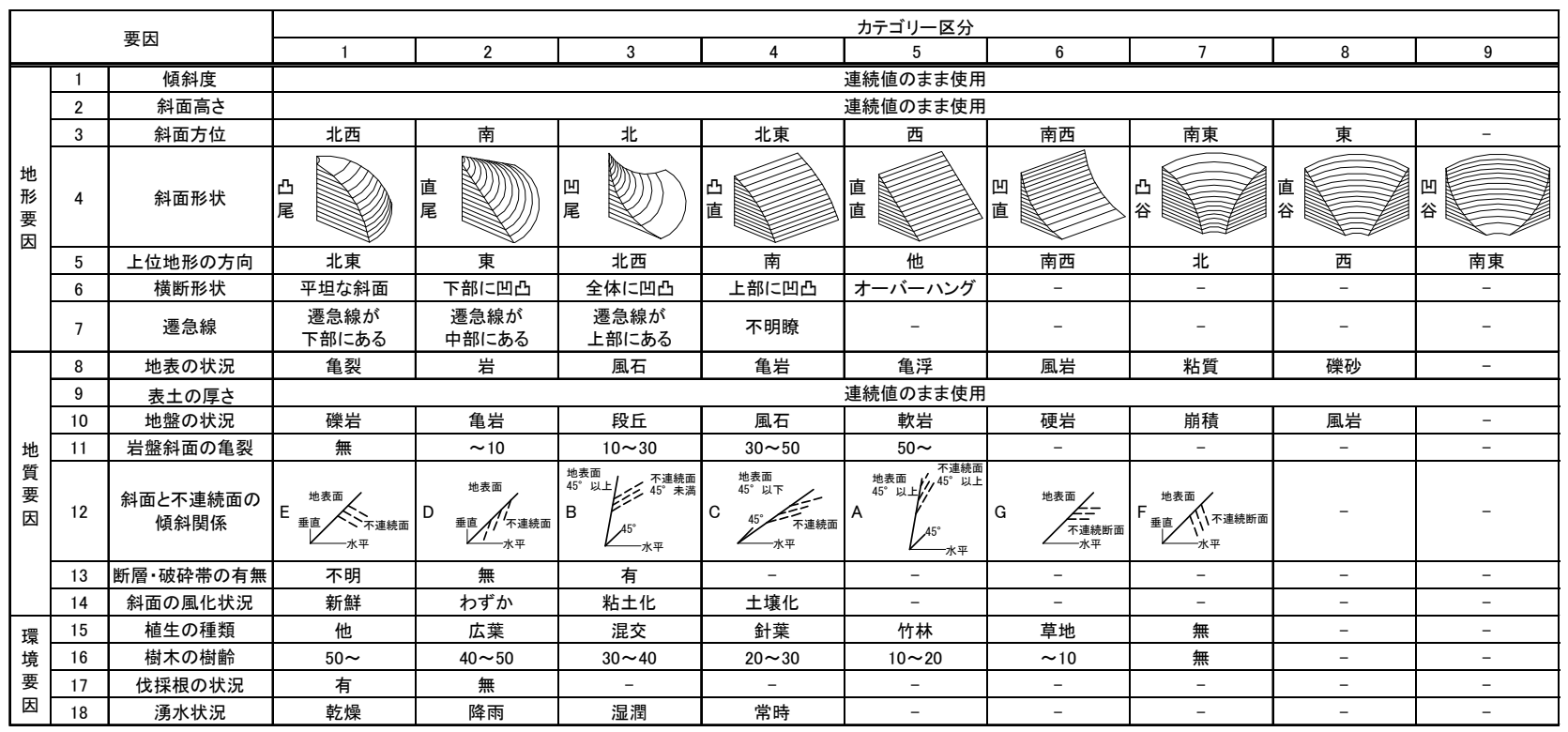

※文献6)に加筆

壁工のみの斜面でも災害が起こり得ると考えられる（図 -4）. このような考えに基づき，疑似データを追加し， SVM 解析に用いることとした. 疑似データとして用い る災害データの概念図を図-4 に示す。また，疑似デー 夕追加後の災害件数を表-1の( )内に示す.

\section{(3) 地形・地質データ}

分析に用いる地形・地質的な素因は, H11 斜面カルテ に整理されている調査項目のうち，表-2 に示す 18 要因 を用いることとした. ここで，斜面方位や斜面形状など， 項目で整理されている要因 ${ }^{6}$ ) (要因番号 3〜8，10～18) のカテゴリー区分は，危険性の大小が想定できる要因 (要因番号 4, 6, 7, 11，13～16, 18）の場合は最も安 全側に該当する項目から $1 ， 2 ， 3 ， \cdots$ と区分し，危険性 の大小の想定が困難な要因（要因番号 $3 ， 5 ， 8 ， 10,12$,

17）はそれぞれに次式で求めた災害発生率が低い項目か ら1，2，3，ㄷと区分した.

$$
\text { 災害発生率 }=\frac{\text { う災害発生箇所数 }}{\text { 各項目に該当する箇所数 }} \times 100
$$

\section{SVMを用いた対策工選定フローの設定}

\section{（1）SVMを用いた危険度評価基準の設定}

SVM 解析では，分離面と各データとの距離 $f(x)$ を算出 して危険度を評価基準にすることから ${ }^{3)}$ ），最適な解析 を行うためのパラメータスタディが必要である. ソフト マージン法を利用した SVM では，誤判別の度合いを調 整する $C$ とガウシアンカーネルの半径（データの影響
表-3 的中率 100\%となるパラメータにおける $f(x)$ 值カテゴリー毎のデータ分布

\begin{tabular}{|c|c|c|c|c|c|c|}
\hline \multicolumn{2}{|c|}{ パラメータ } & \multicolumn{4}{|c|}{$f(x)$ 值カテゴリー毎のデータ個数 } & サポート \\
& $r$ & $f(x)<-1$ & $-1 \leqq f(x) \leqq 0$ & $0<f(x) \leqq 1$ & $1<f(x)$ & ベターの数 \\
\hline \hline 5 & 2 & 1 & 55 & 390 & 210 & 445 \\
\hline 10 & 2 & 1 & 55 & 402 & 198 & 457 \\
\hline 50 & 4 & 4 & 52 & 171 & 429 & 223 \\
\hline 100 & 5 & 4 & 52 & 158 & 442 & 210 \\
\hline 200 & 6 & 4 & 52 & 150 & 450 & 202 \\
\hline 300 & 7 & 4 & 52 & 141 & 459 & 193 \\
\hline 400 & 7 & 4 & 52 & 146 & 454 & 198 \\
\hline 500 & 8 & 4 & 52 & 139 & 461 & 191 \\
\hline
\end{tabular}

※各Cの中でサポートベクターが最小となる $r$ のみを記載

度）である $r$ の 2 つパラメータを設定する必要がある 本研究では， $C=5 ， 10 ， 50 ， 100 \sim 500$ (100刻み）の8ケ 一ス, $r=1 \sim 10$ (1刻み) の 10 ケースの計 80 通りの組合 せについて検討を行った，パラメータスタディでは，次 式に定義する的中率と既往研究 》におけるパラメータの 選定方法を参考に，的中率 $100 \%$ の゚ラメータセットの

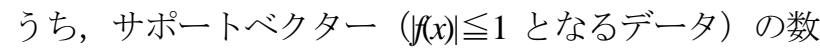
が最も少なくなる $C=500, r=8$ の組み合わせ（表-3 中の ハッチング箇所）を最適なパラメータとして採用した.

$$
\text { 的中率 }=\frac{\text { 的中データ数 }}{\text { 全データ数 }} \times 100
$$

\section{(2) 斜面危険度および対策工効果の算出}

選定したパラメータを用いて，SVM 解析により地 形・地質データと過去の災害実績 (発生 : -1, 非発生 : +1）を分析し，災害の発生と非発生を分ける分離面の設 定を行った．また，当該評価基準を用いて個々の斜面の 有する現在の斜面危険度 $f(x) 1$, 対策後の斜面危険度 $f(x) 2$, 斜面危険度の変化量により算出される対策工効果 $E$ の 
表-4 検討結果の一例

\begin{tabular}{|c|c|c|c|c|c|c|}
\hline \multirow[b]{2}{*}{$\begin{array}{l}\text { 箇所 } \\
\text { 番号 }\end{array}$} & \multicolumn{2}{|c|}{ 現状 } & \multicolumn{4}{|c|}{ 対策工施工後 } \\
\hline & 工種 & $\begin{array}{c}\text { 斜面 } \\
\text { 危除度 } \\
f(x) 1\end{array}$ & 工数 & 工種 & $\begin{array}{c}\text { 斜面 } \\
\text { 危除度 } \\
f(x) 2\end{array}$ & $\begin{array}{c}\text { 対策工 } \\
\text { 効果 } \\
E\end{array}$ \\
\hline \multirow{4}{*}{$\begin{array}{l}326-\mathrm{I} \\
-0031\end{array}$} & \multirow{4}{*}{ なし } & \multirow{4}{*}{-1.00} & 1種類 & 擁壁工 & 1.48 & 2.48 \\
\hline & & & \multirow{2}{*}{ 2種類 } & 擁壁工+落石防止工 & 2.40 & 3.40 \\
\hline & & & & 擁壁工+法枠工 & 3.54 & 4.54 \\
\hline & & & 3 種類 & 擁壁工+法枠工+落石防止工 & 3.54 & 4.54 \\
\hline \multirow{4}{*}{$\begin{array}{l}208-I \\
-0211\end{array}$} & \multirow{4}{*}{ なし } & \multirow{4}{*}{-1.00} & 1 種類 & 擁壁工 & -0.31 & 0.69 \\
\hline & & & \multirow{2}{*}{ 2種類 } & 擁壁工+落石防止工 & 1.64 & 2.64 \\
\hline & & & & 擁壁工+法枠工 & 1.31 & 2.31 \\
\hline & & & 3種類 & 擁壁工+法枠工+落石防止工 & 1.96 & 2.96 \\
\hline \multirow{3}{*}{$\begin{array}{c}201-I \\
-0074\end{array}$} & \multirow{3}{*}{ 擁壁工 } & \multirow{3}{*}{-1.00} & \multirow{2}{*}{ 2種類 } & 擁壁工+落石防止工 & 4.38 & 5.38 \\
\hline & & & & 擁壁工+法枠工 & 4.47 & 5.47 \\
\hline & & & 3種類 & 擁壁工+法伜工+落石防止工 & 4.47 & 5.47 \\
\hline \multirow{3}{*}{$\begin{array}{r}208-I \\
-0130\end{array}$} & \multirow{3}{*}{ 擁壁工 } & \multirow{3}{*}{-1.55} & \multirow{2}{*}{ 2種類 } & 擁壁工+落石防止工 & -1.55 & 0.00 \\
\hline & & & & 擁壁工+法枠工 & 0.07 & 1.62 \\
\hline & & & 3種類 & 擁壁工+法伜工+落石防止工 & 1.07 & 2.62 \\
\hline $\begin{array}{l}211-I \\
-0003\end{array}$ & $\begin{array}{l}\text { 擁壁工 } \\
\text { +法枠工 }\end{array}$ & 2.63 & 3種類 & 擁壁工+法枠工+落石防止工 & 2.63 & 0.00 \\
\hline
\end{tabular}

算出を行った．算出した結果の一例を表-4に示寸。

対策工が施工されていない 326-I-0031 は，現在の斜面 危険度 $f(x) 1$ が負值を示寸ため, 災害の危険性が高い斜 面であり対策が必要であると判断できる. 当該斜面に対 策工を施工した場合を想定すると，擁壁工の久を施工し た場合でも対策工効果 $E$ が 2.48 と大きく, 対策後の斜 面危険度 $f(x) 2$ も 1.48 と正值を示寸。そのため, 当該斜 面において擁壁工の施工は有効であると考えられる.

208-I-0211 は，326-I-0031 と同様に未対策であり，かつ 災害の危険性が高い斜面である，当該斜面に擁壁工を施 工した場合を想定すると, 対策工効果 $E$ は 0.69 と正值 を示すため, 擁壁工による災害抑止効果が期待できる.

しかし，対策後の斜面危険度 $f(x) 2$ が-0.31 と負值を示す ため, 十分な安全性が確保できないものと推測される.

そのため, 当該斜面の対策後の斜面危険度 $f(x) 2$ を正值 とするため，擁壁工に落石防止工または法枠工を併用し た対策が必要となる，危険度の算出結果によると，擁壁 工と落石防止工を併用した場合, 斜面危険度 $f(x) 2$ と対 策工効果 $E$ は，法枠工を併用した場合より大きな正値 を示す．これより，当該斜面では擁壁工と落石防止工の 対策が最も効果的となる.

以上のような評価は，他の斜面でも同様に行うことが 可能である．擁壁工が施工された 201-I-0074 と 208-I-0130 は，現在の斜面危険度 $f(x) 1$ が負值を示寸ため，危険な 斜面であると判断できる. 追加対策後の斜面危険度 $f(x) 2$ と対策効果 $E$ の関係から共に法枠工を施工することで 最も効果的に安全性を確保できると判断できる. また,

211-I-0003 は, 現在の斜面危険度 $f(x) 1$ が正值を示すため, 現状でも安全であると判断することができる.

他の箇所についても同様の検討を行い，最適な工種の 選定を行った．結果を図-5 に示す，ここで，本研究で は擁壁工，法枠工，落石防止工の 3 工種が併用されてい る斜面までを対象としたことから，3 工種が併用されて
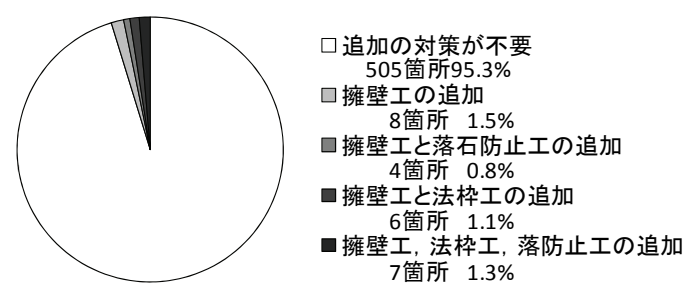

図-5 効果的な工種選定結果

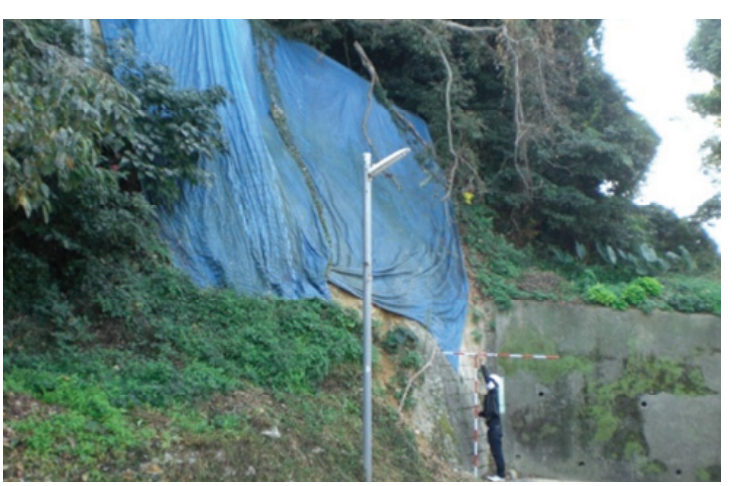

写真-1＼cjkstart現地状況写真（201-I-0074）

いる斜面は対策後の斜面危険度 $f(x) 2$ が算出できていな い, そのため, 図中からは除外している.

図-5 より，全体の約 95\%の箇所において現在設置さ れている対策工により十分な安全性が確保されているこ とが確認できる.

\section{（3）対策工効果の妥当性評価}

設定した対策工選定フローにより対策が必要と判断さ れた箇所を対象に現地調査を行い，対策工選定フローに 基づいた対策工選定結果の妥当性の確認を行った. 現地 調査結果の一例を以下に示す。

\section{a) 箇所番号201-1-0074}

201-I-0074 は，現在，擁壁工が施工されている箇所で ある，対策工選定フローによる選定では，現在の擁壁工 に加え，法枠工を追加施工した際，最も効果的であると 評価されている（表-4）。

当該斜面の現状を写真-1 に示寸. 斜面の上部は荒れ ており，擁壁工の上部斜面においてブルーシートで覆わ れた小規模な表層崩壊跡が見られた．対策工選定フロー により効果的と評価された対策は，法枠工である。もし， この対策工を施工していれば現地で確認された崩壊を最 小限に抑えることが可能となったものと考えられる.

\section{b) 箇所番号208-I-0130}

208-I-0130 は，現在，擁壁工が施工されている箇所で ある．対策工選定フローによる選定では，現在の擁壁工 に加え法枠工を追加施工した際, 最も効率的であると評 価されている（表-4）.

当該斜面の現状を写真-2 に示寸，当該斜面では新た に法枠工と落石防止工が追加で施工されていることが確 


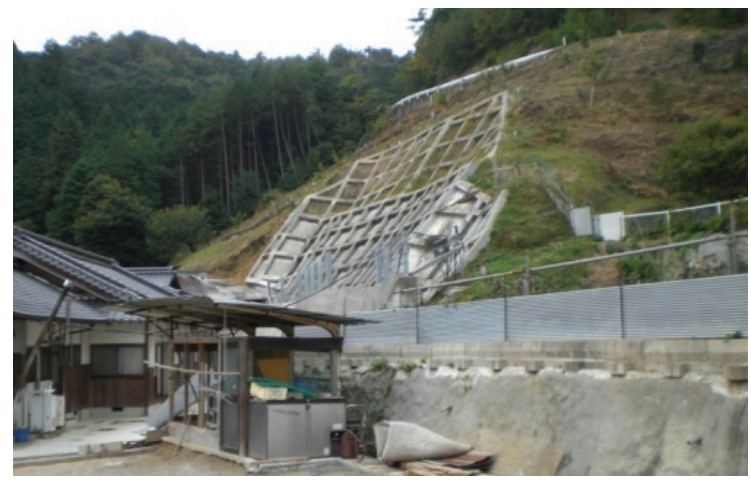

写真-2 現地状況写真 (208-I-0130)
検討で対象とした危険箇所の約95\%の箇所において 現在設置されている対策工により十分な安全性が 確保されていることが確認された.

3) 本研究で設定した対策工選定フローに基づいた対 策の要否および最適な対策工は，現地状況から得 られる知見と一致する妥当な結果であった.

本研究では，急傾斜地崩壊危険箇所調査データ1)を用 いて斜面災害の防止に関する対策工に限って検討を行っ てきたが，今後は道路法面や地すべり危険箇所の対策施 設等，より幅広い分野への適応に取り組む次第である.

\section{参考文献}

1）例えば，山口県下関土木建築事務所：管内一円情報 基盤緊急整備事業に伴う斜面カルテ(急傾斜)作成業務 委託, 報告書, 1999 .

2) Cortes, C. and Vapnik, V.: Support vector networks, Machine Leaming, Vol.20, pp.273-297, 1995.

3) 大石博之, 小林央宜, 尹禮分, 田中浩一, 中山弘隆, 古川浩平 : サポートベクターマシンによる対策工効 果を考慮した斜面災害危険度の設定，土木学会論文 集 F，Vol.63，No.1，pp.107-118， 2007.

4) 山口県土木建築部砂防課：連携案方式による土砂災 害警戒避難基準雨量等の検討業務委託, 報告書, 2006.

5) 杉本博之, 阿部淳一, 古川浩平 : 応答局面支援のた めの SVM に関する基礎的研究, 土木学会第 61 回年 次学術講演会, pp.1051-1052, 2006.

6) 例えば，(社)全国治水砂防協会 : 砂防関係法令例規集, 平成 15 年版, pp.772-804, 2003.

本研究で得られた主要な結論を以下に示す.

1) 工種別にSVMによる解析を行うことで，既往の研 究では表現されなかった新たな対策工を施工した場 合の対策工効果の評価が可能となった.

2) 本研究で提案する手法を用いて新たな対策工を施 工した場合の対策工効果の評価を行った結果，本
7）篠崎嗣浩, 森田真人, 大石博之, 古川浩平 : SVM と ラフ集合を用いた土石流の発生・非発生ルールの作 成方法に関する研究, 土木学会論文集 F, Vol.65, No.4, pp.448-460, 2009.

(2011. 3. 4 受付)

\title{
DETERMINATION OF COUNTERMEASURE WORK SELECTION FLOW IN SLOPE DISASTER COUNTERMEASURE PROJECTS
}

\author{
Hisashi SAWADA, Shigemitsu SUGIHARA, Daiki NISHIMURA, \\ Tsuguhiro SHINOZAKI, Hiroyuki OHISHI and Kohei FURUKAWA
}

In order to promote efficiency in slope disaster countermeasure projects, it is important to grasp the hazardous nature of each slope and plan appropriate countermeasure work. In this research, we utilize the support vector machine mathematical technique to try to determine countermeasure work selection flows for hazardous slopes. First of all geographical and geological predisposition and past disaster history is used to determine slope hazard level and need for countermeasure work, and slope hazard evaluation standards are set for each construction type. These evaluation standards are used to calculate the current degree of slope hazard and calculate the slope hazard if new countermeasure work is added. From this it is possible to evaluate what kind of countermeasure work would be most effective for each slope.

We conducted a site investigation of locations judged as requiring countermeasures by the set countermeasure work selection flow. The results showed that, the selection of countermeasure work was consistent with knowledge of engineers gained from the local conditions, and we believe the fruits of our research will be effective techniques in considerations of disaster prevention project plans. 